\title{
The Models of North Sumatra Provincial Government Policy in Resolving the Ex-Hgu Land Conflicts of PTPN II Plantations in Deli Serdang Regency
}

\author{
Isnaini $^{1}$, Rizkan Zulyadi ${ }^{1}$, Abdul Kadir ${ }^{2}$ \\ ${ }^{1}$ Faculty of Law, University of Medan Area, Indonesia \\ ${ }^{2}$ Public Administration Study Program, Faculty of Social and Political Sciences, University of Medan Area, \\ Indonesia \\ isn25@yahoo.co.id
}

\section{Abstract}

This study is to find an alternative model of North Sumatra provincial government policy in resolving the ex-hgu land conflicts of PTPN II plantations in Deli Serdang Regency. This study is based on the fact that regional autonomy as regulated in Law Number 23 of 2014 gives the authority to the regional government in autonomy to resolve disputes over arable land in their territories. One of them relates to ex-HGU PTPN II land disputes starting in 2002 with the Central BPN Decree number 42, 43 and 44 / HGU / BPN / 2002 and Decree Number 10/2004 regarding the granting of an extension of the term of the Right to Cultivate (HGU) covering an area of 5,873, 068 Ha from PTPN II HGU. However, the problem arises because of legal uncertainty over the distribution of land that had expired during the PTPNII HGU, so that horizontal or vertical conflicts (community cultivators, PTPN II, government and developers) occurred. From the results of the study, it was concluded that first, the ineffective model of handling policies that are appropriate, fast, and comprehensive is carried out by the government. This relates to the problem of land conversion where there is a lack of orderly administration and past land data. So that each party has its own claim on land ownership and ownership. Both the boundary and location of land parcels. Second, legal uncertainty, that there are legislation that overlaps both horizontally and vertically as well as regulated substance.

\section{Keywords}

community, PTPN II, land

conflicts, policy models

\section{Introduction}

Land disputes and conflicts are complex and multidimensional problems. Therefore, efforts to prevent, handle and resolve must take into account various aspects, both legal and non-legal. Often the handling and resolution of land disputes and conflicts is faced with dilemmas between different interests that are equally important. Finding a balance or win-win solution for conflicts that already occur clearly requires effort that is not easy. Legislation that applies to land acquisition does not accommodate the paradigm of community development that is just, prosperous, and prosperous. The discrepancies between the forms of policy regulation often lead to disputes or conflicts.

Conflict disputes that occur in North Sumatra are generally between the community and the community, the community with BUMD / BUMN, the community with Private Legal Entity and Private Legal Entity with Private Legal Entity. The same is true of the Ex-HGU PTPN II land conflict that began in 2002 between the cultivating communities and PTPN II and even the developers with the emergence of the Central BPN Decree No. 
42, 43, and 44 / HGU / BPN / 2002 and Decree No. 10/2004 regarding Provision of Extensions Period of Cultivation Rights (HGU). In this case the Government through BPN issued land of 5.87,068 Ha from PTPN II's HGU, from 5,87,068 Ha covering 3,366.55 Ha located in Deli Serdang Regency, then 1,210, $868 \mathrm{Ha}$ in Langkat Regency and 238,52 Ha in Kota Binjai, while an area of 1,057.13 hectares is still awaiting the decision of the Central BPN.

The release of the land release policy which was not extended by the HGU's validity period turned out to be a problem. Because the land expenditure covering an area of 5.87.068 Ha from the PTPN II HGU was not strengthened by mapping the land position. While the central government only mentions the total land area in each region without mentioning locations such as villages, sub-districts and land boundaries that are easy to identify.

Therefore, with the aforementioned problems it is important to analyze the Deli Serdang Regency government policy model in resolving ex-HGU PTPN II land conflicts in Deli Serdang Regency, in order to create and realize justice and public welfare within the framework of the Unitary Republic of Indonesia (NKRI).

\section{Research Methods}

This study uses a normative juridical approach (Johny, 2006) and the type of legal study is analytical comprehensive on primary legal materials, secondary legal materials, and tertiary legal materials. Normative legal research examines laws that are conceptualized as norms or rules that apply in society, and serve as a reference for everyone's behavior. The prevailing legal norms are in the form of positive written legal norms formed by statutory bodies (Basic Laws), codifications, laws, government regulations, and so on and written legal norms formed by judicial institutions (judge made law), and artificial written laws interested parties (Abdulkadir, 2004).

\section{Discussion}

\subsection{The Chronology of Land Conflict in Ex-HGU PTPN II Plantations}

The history of the ex-HGU PTPN II land could be traced back to 1999-2000 when PTPN II proposed an extension of the 62,161 hectare HGU which would end in 2000. The land was an ex PTPN II area of 18,996 hectares and an ex PTPN IX of 43,164 hectares. Consisting of 66 gardens spread across three regencies / cities, namely: Deli Serdang, Langkat and Binjai. Since the application for the extension of the HGU in the process, claims / claims / applications for the HGU area began, on the basis of customary rights, and the return of former arable land through demonstrations and even anarchist in nature to the Governor's office, the Regent / Mayor's office and to the office BPN RI region and local DPRD.

Government is not built to serve its own needs, but aims to serve the needs and interests of the community and create conditions that allow each member of the community to develop their abilities and creativity to achieve common goals (Perdana, 2019). It is known that the central government through the Decree of the National Land Agency stated that the extension of HGU covers an area of 56,342.85 hectares. While those that were not issued or given an extension of land area of 5,873.06 hectares from PTPN II's HGU. Of the 5,873.06 hectare land area, 3,366.55 hectares are located in Deli Serdang Regency, 1,210,868 hectares in Langkat Regency and 238,52 hectares in Binjai city. Meanwhile, an area of 1,057.13 hectares is still waiting for the decision of the head of the central BPN. 
The slow process of settlement (distribution) of ex-HGU PTPN II land has become increasingly complex because it involves so many actors. Previously, the most obvious conflict between PTPN II and the community, but now it has expanded to be between entrepreneurs against entrepreneurs, communities with speculators "land mafia", communities and communities, youth organizations (OKP) with the community even with youth organizations as well. The local community's lack of understanding about the law is mixed with the unprofessionalism of law enforcers in responding to conflicts in ex-HGU PTPN II land.

Responding to the issue of the extension of the HGU, initially the Governor who at that time Tengku Rizal Nurdin had formed the B Plus committee in accordance with the Decree of the Governor of North Sumatra No 593.4 / 065 / K / 2000 dated February 11, 2000 Jo No 593.4 / 2060 / K / 2000 concerning problem resolution / The people's demands / claims on PTPN II's land. The B Plus committee consists of the North Sumatra Provincial Government, Deliserdang Regency Government, Langkat, Binjai City and North Sumatra BPN. While PTPN II as an applicant and the public was not included. The reason is that the B plus committee is a team that is given the task of conducting an examination of the land demanded by the people and the land proposed for an extension of the HGU by PTPN II. The results of the examination of the Committee B plus are set forth in the Decree of the Central BPN Number 51.52.53.57 and 58 of 2000. Then refined with the issuance of the Decree of BPN Number No, 42, 43, and 44 / HGU / BPN / 2002 and SK number 10 / 2004 concerning the Granting of an Extension of the Right to Cultivate Rights.

The planned designation of the ex- HGU PTPN II area of 5,873.06 hectares is known to be 2,641.47 hectares for the General Spatial Plan for the Regency and City Areas (RUTRWK). The rest, meet the demands of the people who have legal rights, for the demands of the community covering $1,377.12$ ha, the work of the people covering 546.12 ha, for the request of retired employees of PTPN II covering an area of 558.35 ha, for the indigenous community as an award to the indigenous Malay people covering an area of 450.0 ha and the development of the campus of the University of North Sumatra (USU) covering an area of 300 ha (Bureau of Provincial Administration of North Sumatra Province).

In general, the term "policy" used to designate the behavior of an actor (for example an official, a group, as well as a government agency) or a number of actors in a particular area of activity. The term policy is distinguished from the word wisdom meaning wisdom or wisdom. Policy is a general statement of behavior than organization (Purba, 2019). The release of the land release policy which was not extended by the HGU turned out not to be a solution but instead raised a problem. The execution of the distribution of ex-HGU PTPN II land was apparently hampered by regulations and administration. In addition, the distribution of 5,873,068 ha of land from the PTPN II HGU was not accompanied by a map of land position. The central government only mentions the area of land issued and the amount of land in each region without mentioning the location of villages, sub-districts, especially land pegs that facilitate identification of the land. If observed in the Central BPN Decree No. 42, 43, 44 / HGU / BPN / 2002 and 10/2004, it is clear that plantation land that is not extended will be land that is directly controlled by the state and submits its arrangements to the Governor of North Sumatra for processing according to the rules and regulations. Applies after obtaining a permit to release assets from the authorized minister (BUMN). But until now the document for releasing assets from the ministry has not been issued. This condition has led to protracted community conflicts and PTPN II, also provided space for land speculators to seize ex-HGU land (Ngadimin, 2018). The reality of conflict continues until now that has not been resolved. 


\subsection{The Identification of the Root Issues of Ex-HGU PTPN II Plantations Land}

Nearly 20 years of resolving 5,873 hectares of ex HGU land in North Sumatra in North Sumatra. So complicated and so complex. From the point of view of institutional institutions that the protracted problem was identified because of the lack of effective communication and coordination between PTPN II and the North Sumatra Provincial Government, between the North Sumatra Provincial Government and BPN as well as between BPN and PTPN II. Each institution points to each other and there is no good communication.

The confusion of land ownership also occurs in the community. The community claims that the peasants and cultivators are entitled to own according to the provisions of the prevailing laws and regulations, because they have worked for long enough, mastered and fought against oppression / violence in order to maintain the rights to the cultivated land. Another problem is the involvement of speculators of "land mafias" in the land issue of the former PTPN II HGU. Also problems that occur in the field of fake correspondence owned by parties who want the land, especially given to housing developers, developers who have never mastered and managed the land easily obtain land cultivated by residents, and by building luxury homes in over arable land that has been fought for long enough. Ex HGU land that was distributed to luxury housing developers made the conflict escalated.

The policy of resolving land conflicts often forgets the most fundamental issue which is the recognition of land rights that can be enjoyed by the people. Whereas the Government is obliged to restructure and prioritize policy instruments in order to guarantee land and natural resource management that is coherent with the development agenda. Development must consider environmental preservation, or in other words maintain environmental balance (Kholil, 2019). Add to this the massive practice of violence and criminalization aimed at groups of farmers and tenants who want to continue to fight for their rights in the ownership of land and natural resources that can advance their lives and livelihoods.

The B Plus Committee, which is the Team that should defend and give community rights, does not give land rights to the residents and does not recommend the residents' land to be excluded from the PTPN II HGU area on the B Plus Committee Matrix List, even though they have land redistribution data for land reform objects in the form of a Long List and the Tracing Map (clack map) that receives the right to redistribute the landreform object. It can be said that data accuracy and administration of land ownership are also a problem. Even the government itself does not know the real map of PTPN II's former HGU land in North Sumatra. Seen when the North Sumatra DPRD Special Committee participates in resolving the Ex-HGU PTPN II land issue (Ex-HGU PTPN II Special Committee) questioned the actual distribution map of where the ex-HGU PTPN II land was to the North Sumatra BPN Region. This was questioned during the Special Committee Meeting with the Ex-HGU PTPN II Land Management Inventory Team. On this occasion stated that the Special Committee had several times requested the map through an official meeting and had even officially written. However, no maps were submitted to the Special Committee, so the Special Committee was not optimal in discussing this problem due to the unavailability of data. The exact coordinates are not known anywhere, its size is unclear and the land is presumed to be currently controlled by land mafias, property mafias, community cultivators and partly still controlled by PTPN II itself.

Finally, the polemic that ensued and was incomplete to this day was that 5,873.06 Ha of land released from the HGU had not yet been distributed to the community because of confusion about the process and mechanism regarding the applicable provisions relating to the release of the land rights. Also a government program through the Ministry of Agrarian Affairs and the National Land Agency, namely land certification or the Complete Land Registration System (PTSL) which until now, also has not touched the lands of the former 
PTPN-II HGU. In fact, among the lands scattered in Deliserdang Regency and several other areas in North Sumatra, there is no more PTPN-II HGU and has long been physically controlled by the community, in fact, many have become dense and compact residential areas. Until now, there has not been a former PTPN-II HGU land that has been certified in the land certification program or PTSL. Even though the program has been going on for several years. In North Sumatra it has been started since 2016.

The province of North Sumatra, until 2017, has covered 290,000 parcels of land. With details of 40,000 plots of land in 2016 and 250,000 plots of land in 2017. This year 2018 is targeted to be 320,000 plots. Unfortunately, of the 290,000 fields that have been certified, there is no land yet from the former PTPN-II HGU. In line with that, the Government should prioritize the land certification program or PTSL in North Sumatra over ex-HGU PTPN II lands. This is an important priority, because of several considerations. For example, because of the conflict over the land of the former PTPN-II HGU it has been going on for a long time, and even has claimed many lives. This happens because the community has controlled the land physically for a long time and is not given legality and protection.

\subsection{The Model of North Sumatra Provincial Government Policy in Resolving the Ex HGU Land Conflict of PTPN II Deli Serdang Regency}

The main problem in understanding agrarian conflicts is how a person can realize that control of land and natural resources affects all aspects of life, not just assets but also the basis for obtaining economic, social and political power. Inequality in access to land tenure results in gaps between strata of society. Related to land issues in North Sumatra (North Sumatra), land conflicts are more dominated due to the expiration of PTPN II's ex-HGU land that has expired, and is not distributed fairly so that this results in horizontal and even vertical conflicts both communities and entrepreneurs, communities with corporation (PTPN) community with community, community with youth organization (OKP), community with government and even law enforcement (police and military). In line with the view according to Wiradi (2000) states that the problem of land conflicts is a matter of power, politics, which is closely related to economic and social powers. This is used as a tool for the interests of centralizing government policy projects in the name of development in the public interest, carried out by government and private-owned agencies and companies.

The islands of Sumatra and Kalimantan are the areas most vulnerable to land disputes between communities (tenants) and corporations, especially oil palm plantations. North Sumatra ranks second after West Kalimantan as the province with the highest agrarian conflict rate. There are 420 cases of land disputes, and 55 cases of land conflicts in North Sumatra. In fact, there are cases that have been resolved for almost 20 years. And the Deli Serdang area is the regency which ranks first in the highest number of land disputes in the Province of North Sumatra, with a total of 32 cases out of 97 cases. This figure is also related to the first historical factor of oil palm in Indonesia which is located in Deli Serdang (Afandi, 2013).

Land conflicts as we understand them as conflicts that are born as a result of relationships between people or groups related to the problems of the earth and all the natural wealth contained on the surface or in the bowels of the earth. So it must be resolved together. In line with what criminologist Tony F. Marshall (1998) said that the parties concerned with certain violations met together to resolve together how to resolve the consequences of the violations in the interest of the future.

Land conflicts are not really new. But the dimension of conflict is increasingly felt in the present. In line with Nasution's study, (2001), there are a number of records found that; land conflicts in ex- HGU PTPN II land are dominated by uneven and uneven land tenure; 
inequality of ownership rights; lack of alignments to the weak economic groups and cultivators / farmers; lack of recognition of indigenous peoples' rights to land (ulayat rights); community's lack of understanding of the land law; Finally, the weak bargaining position of the community holding land rights in land acquisition.

Constitutionally the regulation of economic problems which includes the economy of natural resources in Indonesia has been regulated in the 1945 Constitution, in Article 33 paragraph (3) reads "The earth and water and natural resources contained therein are controlled by the state and used for the great prosperity of the people". Based on the provisions of Article 33 paragraph (3) it seems clear that in order to improve the prosperity and welfare of the people the role of the state is very much needed.

The intervention of the State in welfare matters as meant in the provisions shows that economic problems are not only monopolies based on market mechanisms, but also the role of the state is needed, especially those related to the fields that control the livelihoods of many people, namely land.

These provisions are also strengthened in Law Number 5 of 1960 concerning Basic Regulations on Agrarian Principles, hereinafter referred to as UUPA. One important legal aspect of the LoGA is the launching of a land reform program in Indonesia. Land reform through land redistribution and compensation procedures in order to limit individual land ownership (Dianto Bachriadi, Gunawan Wiradi; 2011). The aim is to enhance the income and living standards of the land tenure farmers, as a foundation or precondition for carrying out economic development towards a just and prosperous society based on Pancasila. Landreform is a necessity and must be implemented through the Land Redform Land Object Reform (TOL) program which has a very broad dimension to the life of the people of the nation and the State. In other words, the basic understanding of land redistribution is the fair and equitable distribution of lands controlled by the State over the livelihoods of the peasants. The division is confirmed to be the object of Landreform given to smallholder farmers who have fulfilled the requirements of Government Regulation No. 224 of 1961.

Not only referring to the LoGA, the issuance of Presidential Regulation 86 of 2018 on agrarian reform is also expected to be a reference in addressing the issue of land ownership inequality. Supported by various other policies that have been published previously. Such as Presidential Regulation 88/2017 concerning Settlement of Land Tenure in Forest Areas and Presidential Instruction 8/2018 concerning Postponement and Evaluation of Oil Palm Plantation Licensing, Increased Productivity of Oil Palm Plantation, as well as Candy related to social forestry can certainly be opportunities to implement genuine agrarian reform. In addition, the regulation on handling land cases resolution refers to the Regulation of the Minister of Agrarian Affairs and Spatial Planning / Head of the National Land Agency of the Republic of Indonesia Number 11 of 2016 concerning Settlement of Land Cases which aims to provide legal certainty and justice regarding land tenure, ownership, use and use. To provide legal certainty for the holders of land use rights, it is necessary to have land rights which give authority to the holders to physically control and exploit the land they give.

However, reality and legal debate always arise when the HGU of a plantation ends. Because in addition to legal issues also arise economic problems in the community around plantations. Where plantations are not only centers of economic growth for the country they are also a center of poverty for the people and a high Gini coefficient index. It is poverty and social inequality that then make the root of land disputes, especially in North Sumatra. Even though land disputes will not occur if the conditions of social justice can be met by the State or at least the existing social inequality is narrowing.

In the context of HGU, actually it has been regulated in PP No. 40 of 1996. And the issue of the end of the HGU period contained in article 17 which states that; The Right to Use 
is removed due to the expiration of the period as stipulated in the decision to grant or renew it. So it is clear that with the expiration the HGU has been deleted. Whereas in the case of an explanation it is stated clearly. So that the HGU held by PTPN II, which ends in time, becomes Land that is controlled by the State. This means that for the sake of legal certainty concerning the control / ownership of land whose HGU ends, the land is controlled by the State.

This is in accordance with the nature of socially functioning land, meaning that the State as the highest power organization controls the land for the welfare of its people. Because of the social functioning of the land, the law on land is a law of the State Administration. The obligations of the former HGU holder to return the land granted with the HGU to the State after the HGU is abolished and submit the revoked HGU certificate to the Head of the Land Office. Then the Deli Serdang Regency Land Office should withdraw the certificate of ex- HGU PTPN II which has become State land. This means that the ex-HGU land automatically becomes State land (land controlled by the State).

Looking at the results of the study, the tendency occurs when the people who are primarily made as a collective entity in the development agenda are then removed structurally under the pretext of that agenda as well. The policy of resolving land conflicts often forgets the most fundamental issue, namely the recognition of land rights that can be enjoyed by all people. Exploitation of land and natural resources by an elite group is always justified, the argument is in the name of development. Not only were they removed, the peasant groups, cultivators, the poor had to deal with massive practices of violence and criminalization when they wanted to get the right to control their land.

Even though the state has formed many institutions that deal with the resolution of land conflicts, call it the Republic of Indonesia's National Land Agency (BPN-RI), the Ministry of Forestry, the National Commission on Human Rights (Komnas HAM), the Ombudsman Commission of the Republic of Indonesia (ORI), to the House of Representatives Rakyat Republik Indonesia (DPR RI) and DPRD. However, their existence has proven ineffective in resolving conflicts completely. The resulting settlement recommendations have not been binding on the parties to resolve the land conflict. As a result, the conflict continues without any resolution that confirms how the State should act, including providing space for legal certainty and compensation if the conflict leads to violence and gives losses that have a major impact on the people.

In addition to legal issues, PTPN II's HGU land users also do not apply the same rights to the acquisition of state land from the former PTPN II HGU. It is assumed that PTPN II did not respond to the authority of the Regional Government and the people. Moreover, the fact is that PTPN II's HGU has changed many functions. There is no need to wait for the pretext of PTPN II so that until now it has not released its Ex HGU land to the people. PTPN II (Persero) should not apply discriminatory so that social jealousy does not arise which harm all parties because the Ex HGU area is only released to certain parties, especially to other agencies or corporations / Private Parties (such as Housing) for various reasons but at the same time they are not never release to the people who have been working on the land for a long time.

Even though administratively the land has expired but in civil terms it is still attached as an asset, for that the governor must make a proposal to the Ministry of SOEs and the Minister of SOEs proposing recommendations to the Minister of Finance and the Minister of Finance with consideration of PTPN from the Governor as the head of this autonomous region. Book-writing But in this case the Governor must be careful in the distribution of the land must be recorded in advance so that it does not overlap and cause new conflicts. 
The issue of land is implied that it is indeed very complicated for local governments to resolve conflicts in the former PTPN II HGU land. Impressed dilemma and do not want to risk the conflict that is increasingly massive and widespread. However, the firmness in issuing policies to resolve land conflicts must be based on building a legal structure based on the principles of justice, democratic and sustainable. It does not mean anything a policy that is made without consistent and effective law enforcement. So far, law enforcement has become a problem in itself from the broad meaning of law, namely law as a social phenomenon.

So that recommendations for policy models that are based on the principles of justice, democratic and sustainable are absolutely necessary, considering the problem of the stagnation in the implementation of the policy of resolving land conflicts of ex-PTPN II Plantation HGUs as an object of land reform which is not being finished. In an effort to minimize land disputes, a comprehensive strategy is needed to anticipate and reduce the number of incidents in the field of land, so it is necessary to carry out several efforts to address the system of dispute resolution on land based on justice. Among them; the first is the strategic administration of the country, which is professional and comprehensive (multidisciplinary) that is not biased towards interests and is product oriented. The orientation is on changing sectoral organizational structure not based on products but organizational structure on the basis of process. This minimizes sectoral interests in the resulting policies. Second, the strategy of legal institutions, completing the overlapping legislation and recommendations for the formulation of land regulatory umbrella. Third, the legislative / executive strategy, the DPRD and the regional government are obliged to regulate policies related to their regional powers, especially land conflicts. Fourth, the context of handling disputes over government land needs to institutionalize a judiciary that deals specifically with agrarian justice. This is very much needed for justice seekers or people in conflict. So that the judiciary needed legal discovery in order to get social justice based on Pancasila.

Policy models for resolving land conflicts and law enforcement must pay attention to elements of justice (gerechtigkeit), elements of expediency (zweckmassigkeit) and elements of legal certainty (rechtssicherkeit). In all three elements there is a contradiction / antinomy (spannungverhaltnis) between one elements to another. Although contradictory, the three elements must be pursued proportionally in the enforcement of agrarian reform law, so that agrarian justice can be achieved. Simply put, agrarian justice is interpreted as a condition where there is no meaningful concentration in terms of control, ownership, use and use of land and natural resources as well as guaranteed public access to land and natural resources. Access to land and natural resources is at the core of the problem of agrarian justice. And conflict resolution must be in line between political commitment and good legal commitment.

\section{Conclusion}

Concerning the object of the problem, this study provides a conclusion that; First, that local government policy shows that the current legal and institutional administrative system regarding the resolution of land conflicts of ex-HGU PTPN II Plantation that is currently in effect does not touch comprehensively and substantively, which is based on objectives, paradigms, and procedural systems that are not in accordance with the current legal awareness environment this. So that the handling is so protracted due to the ineffectiveness of the right, fast, and comprehensive handler's policy model implemented by the government. This relates also to the problem of land conversion where there is a lack of orderly administration and past land data. So that each party has its own claim on land ownership (community claims and PTPN II). Both the boundary and location of land parcels. From the 
results of research, study and legal analysis can be found sources of the emergence of causes of land disputes include: a. The problem of land conversion to former rights / lack of orderliness in past land administration. b. The problem of control and ownership of land. c. The problem with overlapping location permits. $d$. The problem with boundaries and location of plots of land. e. The problem of land landform objects. Second, the problem of the stagnation in the implementation of the policy of resolving land conflicts of ex-HGU PTPN II Plantation as an object of land reform. Therefore, recommendations for developing a policy model for the North Sumatra Provincial Government in resolving ex-HGU land conflicts in PTPN II in the Deli Serdang Regency area that are based on justice, democratic and sustainable principles are absolutely necessary.

The argumentation is caused by legal uncertainty as well as overlapping horizontal and vertical laws and regulations as well as regulated substance. The complexity of the settlement comes from legal products that have not been responsive to the demands and levels of public legal awareness, institutional factors that are technocratic-based, the capabilities and desires of institutions along with the system of settlement models that are formalistic, bureaucratic, and substantial costs. The gap factor in the legal awareness of government officials and community legal awareness based on different system values. There is no common perception or interpretation of law enforcers and the community towards conflict resolution efforts. The regional government and law enforcers do not yet have a commitment to implement the laws and regulations in an effective, consistent and consistent manner for the justice and welfare of their communities.

\section{References}

Afandi, Muhammad. 2013. Perlawanan Ekstra Legal: "Transformasi Perlawanan Petani Menghadapi Korporasi Perkebunan. Yogyakarta: Bhumi Jurnal Ilmiah Pertanahan PPPM-STPN No. 37 Tahun 12, April 2013.

Abdulkadir, Muhammad. 2004. Hukum dan Penelitian Hukum. Bandung: PT. Citra Aditya Bakti.

Dianto Bachriadi, Gunawan Wiradi. 2012. Enam Dekade Ketimpangan: Masalah Penguasaan Tanah di Indonesia. Bandung: Agrarian Resource Centre, Bina Desa, KPA

Ilyas, Abdurrahman, dan Sufyan, 2015. Kewenangan Pemerintah Daerah Dalam Penyelesaian Sengketa Tanah. Universitas Syiah Kuala. Kanun Jurnal Ilmu Hukum No. 65, Th. XVII (April, 2015), pp. 1-18. ISSN: 0854-5499

Ibrahim, Johny. 2006. Teori dan Metodologi Penelitian Hukum Normative. Jakarta: Bayu Media Publishing.

Kholil, S., et al. (2019). Communication Planning of Langsa City Government in Building an Islamic and Environmentally Friendly City. Budapest International Research and Critics Institute-Journal (BIRCI-Journal), 638-644.

Nasution, Lutfi. 2001. Catatan Ringkas Tentang Pemberdayaan Masyarakat Dalam Pengelolaan Dan Pemanfaatn Tanah. Pokok-pokok Pikiran Dalam Sarasehan Oleh Badan Pertanahan Nasional.

Ngadimin, Heri Kusmanto, Isnaini. 2018. Peran Pemerintah Provinsi Sumatera Utara dalam Proses Penyelesaian Permasalahan Sengketa/Konflik Areal Lahan. JPPUMA: Jurnal Ilmu Pemerintahan dan Sosial Politik UMA, 6 (1) (2018): 25-37 e-ISSN 2550-1305

Perdana, A. A., et al. (2019). Society Response to Mobile Services on Mobile on The Road Investment Services and Integrated One-Stop Licensing Services in Tebing Tinggi City. Britain International of Humanties and Social Sciences (BIoHS) Journal, 44-52. 
Purba, N.A.Y., et al. (2019). The Social and Public Health Impacts that Occurred in Rantau Utara Subdistrict after the Publication of the Labuhanbatu District Regulations No.10 of 2011 about the Swallow Bird Tax, Indonesia. Britain International of Humanties and Social Sciences (BIoHS) Journal, 64-73.

Tony F. Marshall. 1998. Restorative Justice An Overview. Minnesota: University of Minnesota: Centre of Restorative justice and Mediation. Social Works 